\title{
Effect of Ozonized Sunflower Oil on Mast Cell Density in a Model of Atopic Dermatitis in Mice
}

\author{
Zulema Ramírez ${ }^{1 *}$, Lucía González ${ }^{1}$, Sandra Rodríguez ${ }^{1,2}$, José A. Medina², Zullyt Zamora², Lidia A. \\ Fernández $^{2}$, Oscar E. Ledea ${ }^{2}$ \\ 1. Department of Morphological Sciences, Latin American School of Medicine, Havana, Cuba. \\ 2. Division of Research, Development and Innovation, National Center for Scientific Research, Havana, \\ Cuba. \\ * Corresponding author: zulema8003@gmail.com, zulema8003@ nauta.cu
}

Atopic dermatitis (AD) is a chronic inflammatory skin disease related to cutaneous hyperreactivity to environmental triggers that are safe for non-atopic people (1). The evolution of skin lesions due to AD correlates with specific immunological and inflammatory mechanisms, such as excessive infiltration of inflammatory cells (lymphocytes, eosinophils, macrophages and mast cells) and elevated serum levels of immunoglobulin $\mathrm{E}$ (IgE) $(2,3)$. The main therapeutic strategy to treat $\mathrm{AD}$ is the topical use of steroid creams, which contribute to the relief of symptoms without achieving definitive cure and have adverse side effects (2). In this context, it is still necessary to search for new more effective and safer therapeutic strategies in order to treat AD. Ozonized sunflower oil (OSO) is a mixture of active ingredients obtained from the partial ozonation of sunflower oil. Previous studies have shown that OSO has a moderate antiinflammatory effect on mice skin (4). This work aimed to study the effect of topical administration of OSO and an OSO-based cream on mast cell density in atopic dermatitis- induced mice.

Forty-two adult male Balb/c mice were distributed in six groups: one negative control and five groups sensitized with 2,4-dinitrochlorobenzene (DNCB) during 14 days to induce AD (one group received no treatment (AD group) and the other four groups were treated with: Sunflower oil, OSO, 30\% OSO-based cream and Predneomin). Treatments were performed daily from day 15 until day 29. On day 30, skin pieces were taken from the treated area. They were embedded in paraffin and $4 \mu \mathrm{m}$ - thick sections were stained with toluidine blue. Ten histological fields per animal were evaluated using a Canon EOS 1000 D \# 2 digital camera coupled to a Zeiss Primo Star light microscope. Mast cell counts were performed using Image $\mathbf{J}$ program and cell density was calculated. The statistical program Graph Pad Prism version 5.0 was used.

In the negative control group, a limited number of mast cells were observed (Figure $1 \mathrm{~A})$. However, in $\mathrm{AD}$ and $\mathrm{AD}+$ Sunflower Oil group, mast cell density increased and many of mast cells showed morphological changes, such as loss of cell integrity and externalization of cell content, evidencing its degranulation (Figures 1 B, $1 \mathrm{C}$ and 2). The increase in mast cell density causes the release of proinflammatory cytokines that attract granulocytes, which contribute to tissue damage (3). Treatment with OSO caused a non-significant decrease in mast cell density (Figures $1 \mathrm{D}$ and 2). Mast cell density was found to be significantly decreased in the group treated with OSO cream with respect to the AD group. Additionally, no significant differences were found with respect to negative control group, or to Predneomin-treated group. (Figures $1 \mathrm{E}, 1 \mathrm{~F}$ and 2).

The reduction in mast cell density stimulated by OSO indicates a decrease in skin damage caused by AD. Future studies will elucidate whether OSO has an influence on the expression and release of proinflammatory cytokines and on IgE levels. 


\section{References}

[1] D.Y. Leung and Bieber T. Lancet 361 (2003), p. 151.

[2] C. Griffiths, P. van de Kerkhof and M. Czarnecka-Operacz. Dermatol Ther (Heidelb) 7 (2017)

(Suppl 1), S31.

[3] R. Campana et al. Curr Opin Allergy Clin Immunol 17 (2017), p. 269.

[4] Z. Zamora, Y. González, N. Ledón. REDVET VII (2006),

http://www.veterinaria.org/revistas/redvet/n121206.html (accessed May 8, 2019).
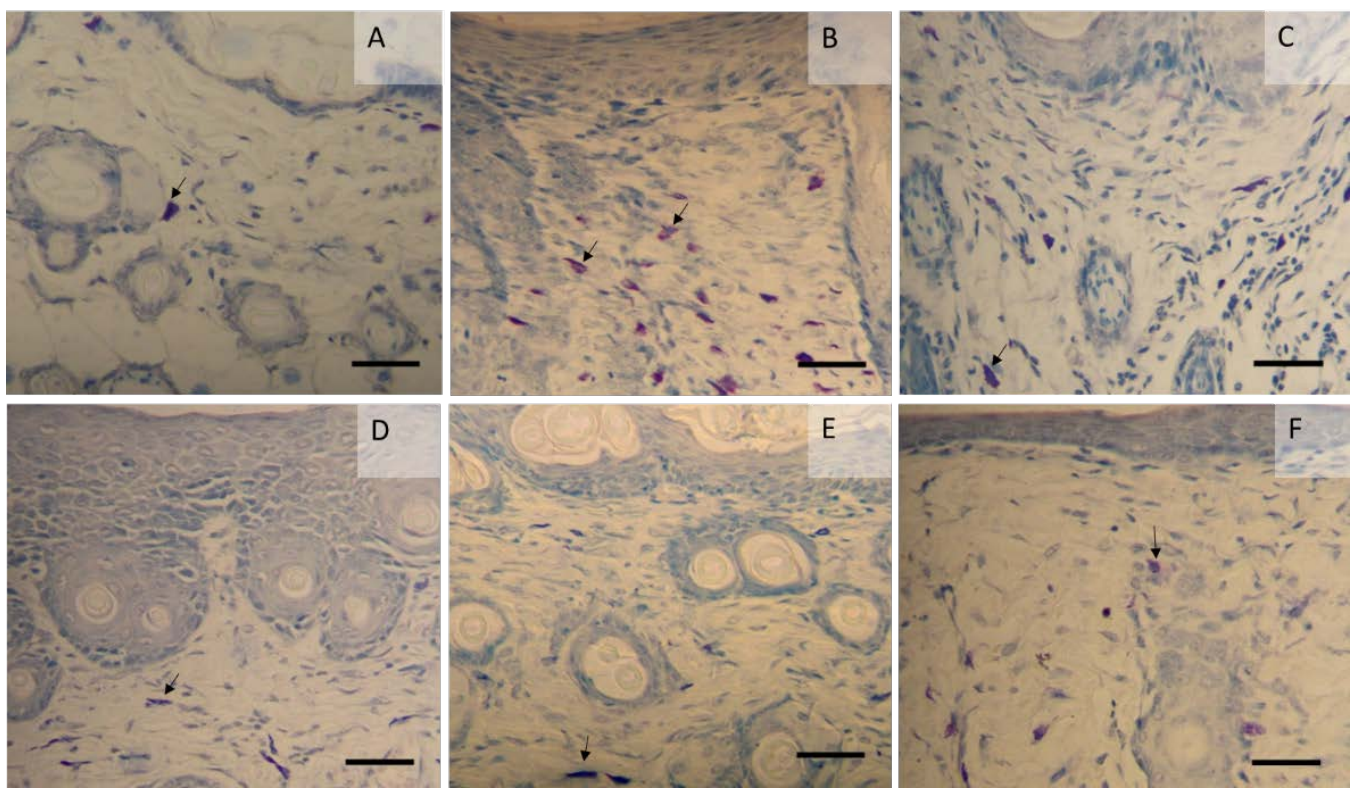

Figure 1. (A-F) Skin micrographs. Toluidine Blue staining. (A) Negative Control group, (B) Atopic Dermatitis group, (C) Atopic Dermatitis + Sunflower Oil group, (D) Atopic Dermatitis + Ozonized Sunflower Oil group, (E) Atopic Dermatitis + Ozonized Sunflower Oil cream $30 \%$ group, (F) Atopic dermatitis + Predneomin group. Arrows: mast cells. Bars $=50 \mu \mathrm{m}$

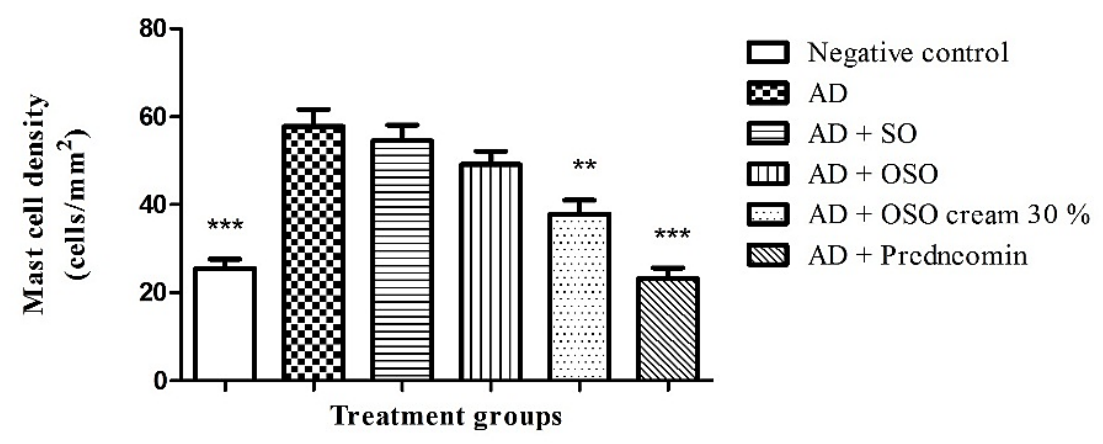

Figure 2. Effect of Ozonized sunflower oil on mast cell density. Atopic Dermatitis Group (AD), Atopic Dermatitis + Sunflower Oil group, (AD + SO), Atopic Dermatitis + Ozonized Sunflower Oil group (AD + OSO), Atopic Dermatitis + Ozonized Sunflower Oil cream $30 \%$ group (AD + OSO cream), Atopic dermatitis + Predneomin group (AD + Predneomin). Kruskal-Wallis and Dunn's multiple comparisons tests. ${ }^{* *} \mathrm{p}<0.01 ; * * * \mathrm{p}<0.001$; all groups compared to the Atopic Dermatitis group (AD). 